\title{
Phytoplankton abundance, dominance and coexistence in an eutrophic reservoir in the state of Pernambuco, Northeast Brazil
}

\author{
GIULLIARI A.S.T. LIRA ${ }^{1}$, ELCIDA L. ARAÚJO ${ }^{1}$, \\ MARIA DO CARMO BITTENCOURT-OLIVEIRA ${ }^{2}$ and ARIADNE N. MOURA ${ }^{1}$ \\ ${ }^{1}$ Programa de Pós-Graduação em Botânica (PPGB), Universidade Federal Rural de Pernambuco (UFRPE), \\ Av. Dom Manuel de Medeiros, s/n, Dois Irmãos, 52171-900 Recife, PE, Brasil \\ ${ }^{2}$ Departamento de Ciências Biológicas, Escola Superior de Agricultura Luiz de Queiroz (ESALQ), \\ Universidade de São Paulo (USP), Av. Pádua Dias, 11, Caixa Postal 9, 13418-900 Piracicaba, SP, Brasil \\ Manuscript received on July 23, 2010; accepted for publication on April 1, 2011
}

\begin{abstract}
The present study reports the phytoplankton abundance, dominance and co-existence relationships in the eutrophic Carpina reservoir, Pernambuco, Brazil. Sampling was carried out at six different depths bimonthly at a single reservoir spanning two climatic periods: dry season (January, September, and November 2006) and rainy season (March, May, and July 2006). Density, abundance, dominance, specific diversity and equitability of the community were determined, along with chlorophyll $a$, and physical and chemical variables of the environment. Eight species were considered abundant, and their densities corresponded to more than $90 \%$ of the total phytoplankton community quantified. Cyanobacteria represented more than $80 \%$ of this density. Cylindrospermopsis raciborskii was the only dominant taxon in the dry season, and was co-dominant in the rainy season. C. raciborskii, Planktothrix agardhii and Geitlerinema amphibium had the greatest densities and lowest vertical variation coefficients. The statistical analysis indicated relationships with vertical and seasonal variations in the phytoplankton community and the following variables: total dissolved solids, water temperature, electrical conductivity and $\mathrm{pH}$. The changes in the environmental variables were discrete and regulated by the establishment of precipitation however, they were able to promote vertical and seasonal instability in the structure of the phytoplankton community.
\end{abstract}

Key words: Carpina reservoir, Cylindrospermopsis raciborskii, Cyanobacteria, limnological characteristics, phytoplankton structure, vertical distribution.

\section{INTRODUCTION}

Most reservoirs are formed by the damming of rivers and are considered hybrid systems between rivers and lakes (Thornton et al. 1990). The importance of these artificial aquatic systems is huge, especially in the northeastern Brazil, which is largely dominated by a semiarid climate, with long periods of drought (Chellapa and Costa 2003). The purposes of reservoirs include providing water for the public, flood control, the production of electricity, irrigation, navigation, the farming of aquatic organisms and recreation.

Correspondence to: Giulliari Alan da Silva Tavares de Lira E-mail: giulliari@gmail.com
Problems regarding artificial eutrophication in reservoirs are common and are caused by anthropogenic actions, which lead to innumerous changes in the structure and dynamics of the phytoplankton community. This community is one of the main groups of primary producers and promptly responds to nutrient changes in reservoir aquatic ecosystems. According to Margalef (1983), the composition of the phytoplankton community and the relationship among its species reflect the scope of such changes in an environment better than any technological tool. Environmental changes frequently stimulates results in high densities of phytoplankton, known as algal blooms, which could compromise wa- 
ter quality and have serious consequences to the health of humans and animals (Bouvy et al. 2003). A classic example of these effects occurred in the city of Caruaru (PE, Brazil) in 1996, with the death of dozens of patients in a dialysis clinic following the contact with water contaminated by toxins released by blooms of Cyanobacteria (Jochimsen et al. 1998).

Knowledge on the structure and dynamics of the phytoplankton community is extremely important to understand the effects of eutrofication, which are fundamental to the comprehension of the behavior and characterization of the community (Crossetti and Bicudo 2005). Despite the increase in phytoplankton research, the scarcity of studies on vertical and seasonal variations in eutrophic ecosystems (especially in northeastern Brazil) lends importance to the present investigation.

There have been a large number of studies on eutrophic ecosystems in Brazil in the last ten years, mainly addressing Cyanobacteria ecology. The dominance and coexistence of species of Cyanobacteria in Marechal Dutra reservoir (Rio Grande do Norte, Brazil) were determined throughout a long dry period with low water transparency, the presence of inorganic nutrients, anoxia of the hypolimnion and high degree of electrical conductivity (Chellapa and Costa 2003). The favorable climatic conditions to the development of phytoplankton and the increasing eutrophication of bodies of water lead to the emergence of blooms of specific invading groups, such as Cyanobacteria (Crossetti and Bicudo 2005). In the state of Pernambuco (Brazil), saxitoxins and anatoxin- $a$ were detected in samples collected from the Tapacurá reservoir during blooms caused by Anabaena spiroides Klebahn, Pseudanabaena sp. Cylindrospermopsis raciborskii (Woloszynska) Seenaya and Subba Raju, and Microcystis aeruginosa (Kützing) Kützing from March to May 2002 (Molica et al. 2005).

The Carpina reservoir in the state of Pernambuco, which is the subject of the present study, was initially constructed for flood control purposes and currently provides water for the surrounding towns, as well as being an important fishing source for the river communities of the region. The Carpina reservoir has eutrophic characteristics once it receives organic and agricultural wastes. From April 2001 to March 2002, the structure of the phytoplankton community of the reservoir had its surface and bottom (not the entire water column) compared, and dense blooms of Planktothrix agardhii (Gomont) Anagnostidis and Komárek were observed (Moura et al. 2007). However, no significant differences were found. The aim of the present study was to carry out a survey of the Carpina reservoir in the northeastern Brazil with regard to the phytoplankton community, addressing seasonal and vertical variations in composition and density, as well as relating these characteristics to limnological and climatic variables.

\section{MATERIALS AND METHODS}

The Carpina reservoir $\left(7^{\circ} 51^{\prime}\right.$ and $7^{\circ} 57^{\prime} \mathrm{S}, 35^{\circ} 19^{\prime}$ and $35^{\circ} 27^{\prime} \mathrm{W}$ ) is located in the coastal plantation zone of the state of Pernambuco (Brazil), and is part of the Capibaribe River basin. The reservoir has an accumulation capacity of approximately $270,000,000 \mathrm{~m}^{3}$. The climate of the region is characterized as warm, humid, pseudotropical according to Köppen classification. There are two distinct seasons: a rainy season from March to August and a dry season from September to February (Moura et al. 2007).

Sampling was carried out at a single point in the reservoir located in the limnetic zone near the dam and spillway $\left(07^{\circ} 53^{\prime} 51^{\prime \prime} \mathrm{S}, 35^{\circ} 20^{\prime} 13^{\prime \prime} \mathrm{W}\right)$ at six depths that were defined based on the indirect calculation of the vertical light attenuation coefficient (Poole and Atkins 1929): a) surface ( $100 \%$ available light); b) $1.0 \mathrm{~m}$; c) $2.0 \mathrm{~m}$; d) $4.0 \mathrm{~m}$; (to $1 \%$ available light); e) $8.0 \mathrm{~m}$; and f) $10.0 \mathrm{~m}$. Sampling was carried out between January and November 2006, spanning three months of the dry season (DS - January, September and November) and three months of the rainy season (RS - March, May and July). The monthly data were treated as repetitions of the climatic seasons and presented as the mean of each period.

In the studied period, the region was climatically characterized by daily and hourly (09:00 am and 3:00 $\mathrm{pm})$ values of the following parameters: air temperature, which ranged from 28.1 to $29.6^{\circ} \mathrm{C}$ in the dry season, and 25.8 to $30.5^{\circ} \mathrm{C}$ in the rainy season; wind direction and speed, which was instable in the dry season, oscillating between southeasterly and easterly and ranging from 2.5 to $3.5 \mathrm{~m} / \mathrm{s}$; wind oscillating between southerly and northeasterly and ranging from 1.6 to $3.5 \mathrm{~m} / \mathrm{s}$ in the 
rainy season. Daily exposure to sunlight ranged from 8.2 to 9.5 hours in the dry season, and from 6.8 to 10.1 hours in the rainy season. Monthly precipitation ranged from 12.3 to $84.0 \mathrm{~mm}$ in the dry season, and from 158.2 to $338.0 \mathrm{~mm}$ in the rainy season (INMET - National Meteorology Institute).

Three samples for the quantitative analysis were collected using a wide-mouth recipient at the surface, and a Van Dorn bottle at different depths was used for the qualitative and quantitative analyses of the phytoplankton community and chlorophyll $a$. The samples for the quantitative analysis were preserved in a solution of acetic Lugol.

The following physicochemical limnological variables were determined: water transparency (Secchi disk $\left.-Z_{\mathrm{ds}}\right)$; euphotic zone, based on Cole (1975) $\left(Z_{\text {euf }}=\right.$ $\left.\mathrm{Z}_{\mathrm{ds}} \times 3.0\right)$; water temperature $\left({ }^{\circ} \mathrm{C}\right)$; dissolved oxygen (mg.L $\mathrm{L}^{-1}$ ), using a field oxymeter (Handylab OX1); turbidity (NTU), using a turbidimeter (model HI93703); $\mathrm{pH}$, electrical conductivity $\left(\mu \mathrm{S} . \mathrm{cm}^{-1}\right)$ and total dissolved solids (mg. $\mathrm{L}^{-1}$ ), using a field YSI device (model 556).

The phytoplankton community was identified with the aid of specialized literature for each group of alga using a binocular microscope (Zeiss, Axiovert). The quantitative analysis (organisms per liter) was based on the method described by Utermöhl (1958) using an inverted microscope (Zeiss, Axiovert), following the calculation method described by Villafaiñe and Reid (1995). Organism counts were carried out on a grid with three repetitions for each depth sampled; the values are presented as the mean of the repetitions. Density values were transformed into scientific notation $\left(\times 10^{4}\right)$.

Chlorophyll $a$ analysis was based on the method described by Chorus and Bartram (1999) using heated 90\% alcohol. Chlorophyll $a$ was used for the determination of the trophic state index - TSI (Chl- $a$ ), along with the transparency values obtained from the Secchi disc, following the method described by Carlson (1977) and modified for tropical environments by Toledo Jr. (1983).

For the analysis of the abiotic variables, mean $(\bar{X})$, standard deviation $(\sigma)$ and coefficient of variance $(C V)$ values were determined. Abundance and dominance were determined from the density data, following the criteria proposed by Lobo and Leighton (1986). Abundant species were those with values above the mean value of the community, and dominant species were those with values surpassing $50 \%$ of the total density. Species diversity and evenness indices (bit.cel. ${ }^{-1}$ ) were calculated based on the methodology proposed by Pielou (1977) using the "Diversity" statistical program. The scaling of the data was performed using principal component analysis (PCA) with the aid of the NTSYS statistical package (version 2.1). The data were then selected for the subsequent correlations of the sample units, environmental variables and abundance species, using canonical correspondence analysis (CCA) with the aid of the PC-Word program. Significance among the data was assessed using the Monte Carlo permutation test $(\mathrm{p}<0.05)$ with the aid of the PC-Word program.

\section{RESULTS}

\section{ABIOTIC VARIABLES}

The highest mean air temperature, wind speed and exposure to sunlight values occurred in the first month of the rainy season. Precipitation was typical for the region. The depth of the Secchi disc (0.30 to $0.70 \mathrm{~m}$ in the dry season and 0.40 to $0.85 \mathrm{~m}$ in the rainy season) and the eutrophic zone ( $\left.Z_{\text {euf }}\right)$ (0.90 to $2.10 \mathrm{~m}$ in the dry season and 1.20 to $2.55 \mathrm{~m}$ in the rainy season) exhibited little variation between seasons, with slightly higher values in the rainy season. The vertical light attenuation coefficient ranged from 2.40 to $5.60 \mathrm{~m}$ in the dry season, and from 2.0 to $4.25 \mathrm{~m}$ in the rainy season, with a total absence of light beginning at the depth of $6.0 \mathrm{~m}$.

The water column exhibited an average pattern of low stratification throughout the entire study $(\sigma=0.3$; $\mathrm{CV}=1.0)$ and slightly higher values in the rainy season. Water temperature $(\bar{x}=27.5$ in the dry season; $\bar{x}=28.1$ in the rainy season), dissolved oxygen $(\bar{x}=$ 4.38 in the dry season; $\bar{x}=5.18$ in the rainy season), electrical conductivity $(\bar{x}=1914$ in the dry season; $\bar{x}=2060$ in the rainy season), total dissolved solids $(\bar{x}=1246$ in the dry season; $\bar{x}=1699$ in the rainy season) and turbidity ( $\bar{x}=23.1$ in the dry season; $\bar{x}=22.0$ in the rainy season) values were higher in the rainy season, whereas $\mathrm{pH}(\bar{x}=8.6$ in the dry season; and $\bar{x}=8.5$ in the rainy season) was slightly higher in the dry season (Fig. 1). 

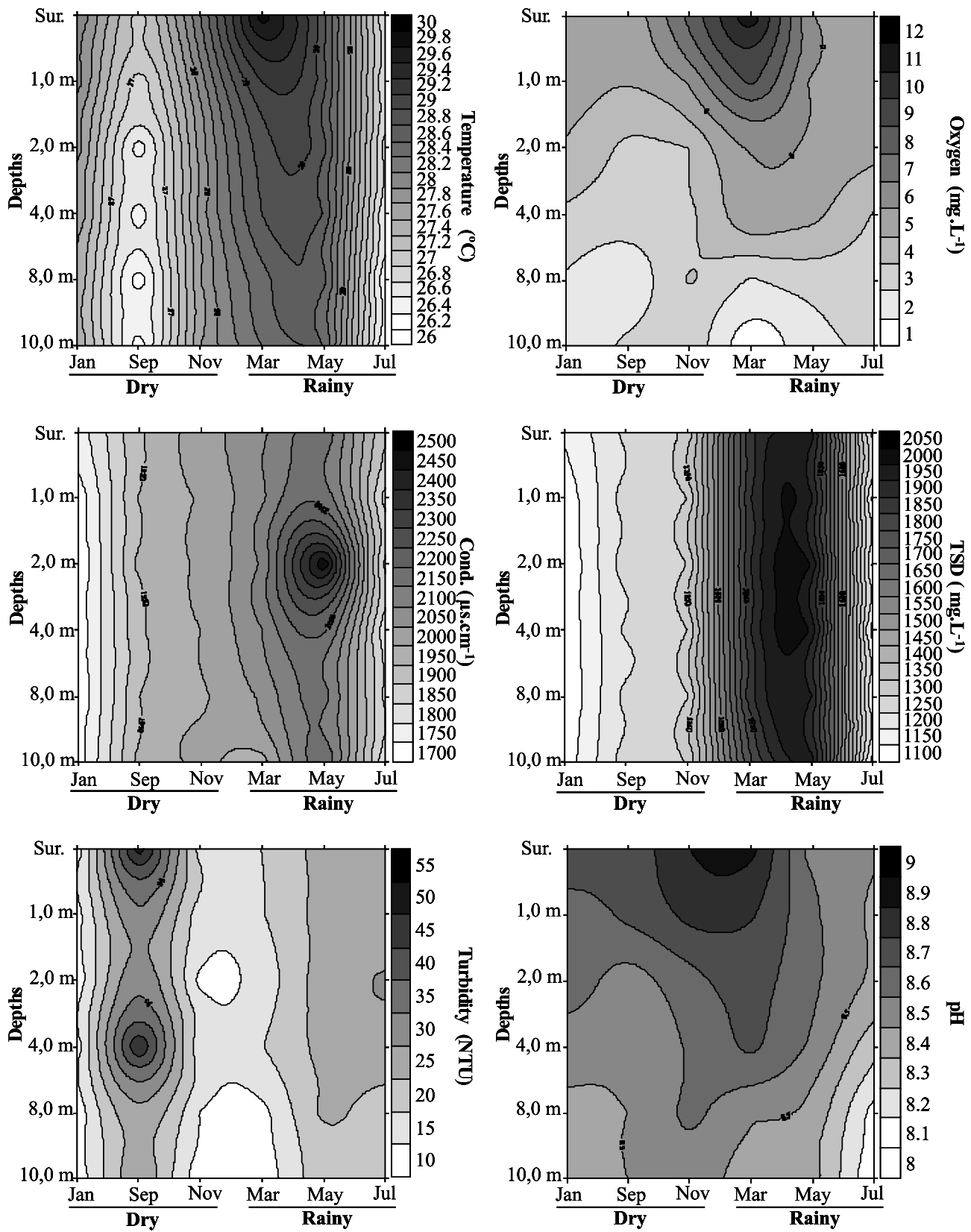

Fig. 1 - Mean seasonal and vertical variation in temperature, dissolved oxygen, electrical conductivity, total dissolved solids, turbidity and $\mathrm{pH}$ in the Carpina reservoir (PE, Brazil) from January to November 2006 (DS: dry season; RS: rainy season).

\section{BIOTIC VARIABLES}

Sixty-one taxa distributed among five divisions were inventoried: 27 Chlorophyta (44\%), 20 Cyanobacteria (33\%), four Euglenophyta (7\%), eight Bacillariophyta (13\%), and two Dinophyta (3\%) (Table I). Chlorophyta had the greatest contribution to taxon richness in both seasons, with a greater number of species in the rainy season, whereas there was a decrease in species of Cyanobacteria in the dry season. The remaining groups exhibited little variation between seasons. Species diversity was discreetly greater in the rainy season. However, there were values ranging from 1.0 to 2.0 bit.cel. $^{-1}$ throughout the study, indicating low diversity in the phytoplankton community. Evenness was $\leq 0.5$, thereby indicating a predominance of one or more species. 


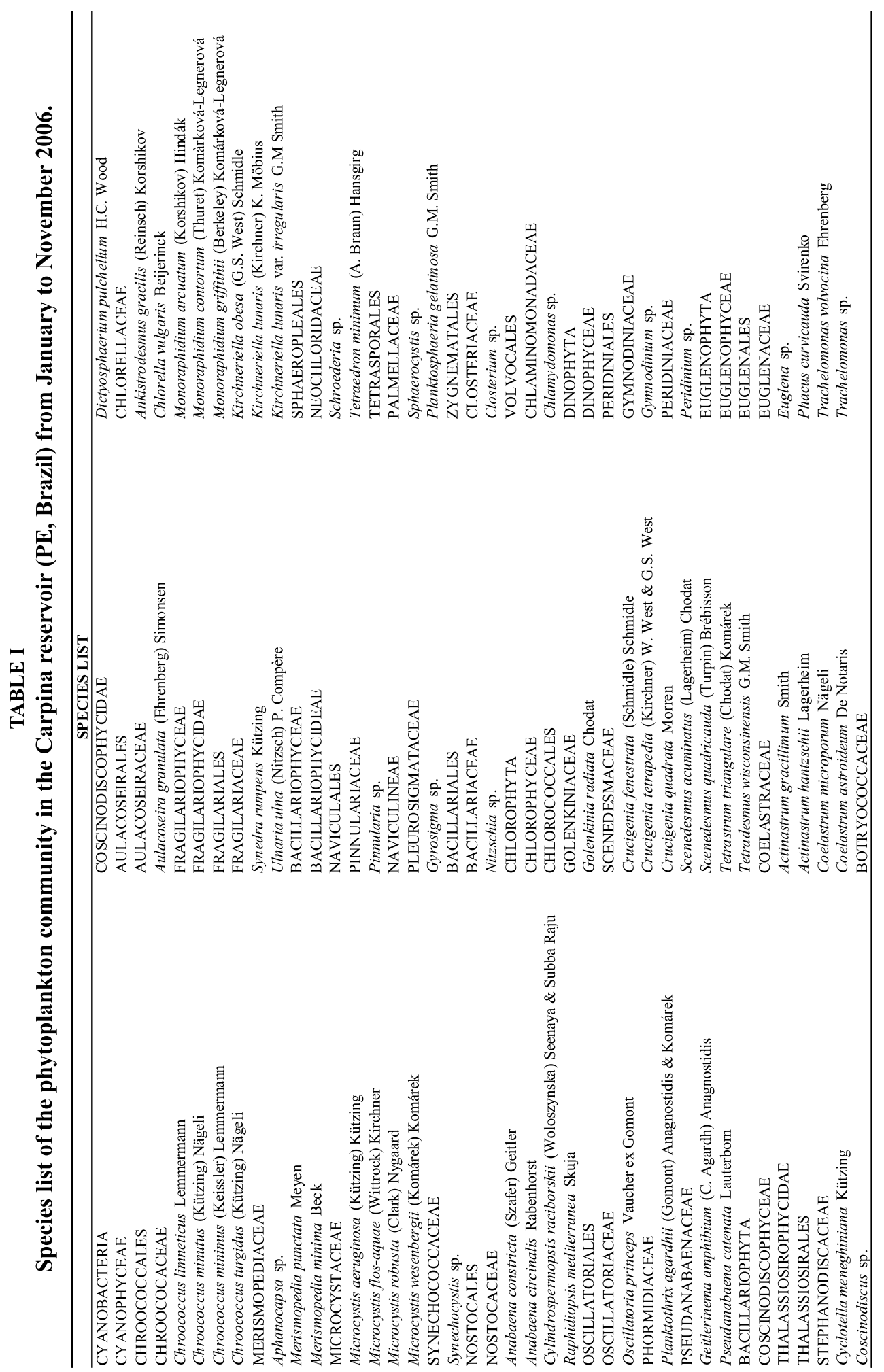


Mean chlorophyll $a$ values ranged from 29.4 to $58.3 \mathrm{mg} . \mathrm{m}^{-3}$ in the dry season, and from 38.6 to $54.1 \mathrm{mg} \cdot \mathrm{m}^{-3}$ in the rainy season. The amplitude of the coefficient of variation for chlorophyll $a$ throughout the water column was twice as large in the dry period compared to the rainy season ( $\mathrm{CV}=26.6 \%$ in the dry season, and $11.8 \%$ in the rainy season) (Fig. 2). The TSI (Chl- $a$ ) ranged from 63.7 to 70.5 in the dry season, and 66.4 to 69.7 in the rainy season (Fig. 2). Among depths, the coefficient of variance for the TSI (Chl- $a$ ) was $3.9 \%$ in the dry season and $1.8 \%$ in the rainy season. The classification of the TSI by the Secchi disc also revealed hypereutropic values, ranging from 65 to 77.3 in the dry season, and 62 to 73.2 in the rainy season.

Mean phytoplankton density ranged from $1410 \times$ $10^{4} \mathrm{org} . \mathrm{L}^{-1}$ (surface) to $1135 \times 10^{4} \mathrm{org} . \mathrm{L}^{-1}(8 \mathrm{~m})$ in the dry season, and from $1798 \times 10^{4}$ org. $\mathrm{L}^{-1}$ (surface) to $1000 \times 10^{4}$ org. $\mathrm{L}^{-1}(10.0 \mathrm{~m})$ in the rainy season. All groups had higher density values in the rainy period, with Cyanobacteria making the greatest contribution $\left[1440 \times 10^{4} \mathrm{org} . \mathrm{L}^{-1}\right.$ (surface) to $889 \times 10^{4} \mathrm{org} . \mathrm{L}^{-1}$ $(10.0 \mathrm{~m})]$, followed by Chlorophyta $\left[154 \times 10^{4}\right.$ org. $\mathrm{L}^{-1}$ (surface) to $60 \times 10^{4}$ org. $\left.\mathrm{L}^{-1}(10.0 \mathrm{~m})\right]$, Bacillariophyta [ $84 \times 10^{4}$ org. $\mathrm{L}^{-1}$ (surface) to $43 \times 10^{4} \mathrm{org} . \mathrm{L}^{-1}(10.0 \mathrm{~m})$ ], Euglenophyta $\left[118 \times 10^{4} \mathrm{org} . \mathrm{L}^{-1}\right.$ (surface) to $7 \times 10^{4}$ org. $\left.\mathrm{L}^{-1}(10.0 \mathrm{~m})\right]$ and Dinophyta $\left[1.2 \times 10^{4}\right.$ org. $\mathrm{L}^{-1}$ (surface) to $0.3 \times 10^{4}$ org. $\mathrm{L}^{-1}$ (2.0 and $8.0 \mathrm{~m}$ )] (Fig. 3).

Cyanobacteria was dominant throughout the study, accounting for an average of $93 \%$ of total density in the dry season, and $84 \%$ in the rainy season, with an average variation among depths of $1063 \times 10^{4}(4.0 \mathrm{~m}) \mathrm{org} . \mathrm{L}^{-1}$ to $1331 \times 10^{4}$ org. $\mathrm{L}^{-1}$ (surface) in the dry season, and from $889 \times 10^{4} \mathrm{org} . \mathrm{L}^{-1}(10.0 \mathrm{~m})$ to $1440 \times 10^{4} \mathrm{org} . \mathrm{L}^{-1}$ (surface) in the rainy season (Fig. 3). The analysis of the vertical pattern revealed that the phytoplankton groups exhibited distinct distribution patterns. In the dry season, homogenous distribution was observed for Cyanobacteria and Chlorophyta $(\mathrm{CV}=8 \%$ and $\mathrm{CV}=$ $16 \%$, respectively). Bacillariophyta was concentrated at intermediate depths $(1.0$ and $2.0 \mathrm{~m})$ and at the deepest depth $(10.0 \mathrm{~m}, \mathrm{CV}=56 \%)$, whereas Euglenophyta occurred primarily at shallow depths $(\mathrm{CV}=80 \%)$. Dinophyta contributed little to the community in the dry season, with larger populations between 2.0 and $4.0 \mathrm{~m}$. In the rainy season, all groups of alga generally exhibited greater concentrations of individuals in the surface strata (surface and $1.0 \mathrm{~m}$ ).

The greater contribution of Cyanobacteria to total density occurred mainly due to blooms of Cylindrospermopsis raciborskii, which ranged from $854 \times 10^{4}$ org. $\mathrm{L}^{-1}$ (surface) to $548 \times 10^{4}$ org. $\mathrm{L}^{-1}(10.0 \mathrm{~m})$ in the rainy season, and from $977 \times 10^{4}$ org. $\mathrm{L}^{-1}$ (surface) to $757 \times 10^{4}$ org. $\mathrm{L}^{-1}(4.0 \mathrm{~m})$ in the dry season, with an approximately $17 \%$ difference between seasons. Greater densities of $C$. raciborskii occurred at the surface in both seasons. However, the coefficients of variation among the depths were low ( $9 \%$ in the dry season, and $14 \%$ in the rainy season), indicating equilibrium in their distribution.

Eleven of the taxa had the greatest contributions to abundance. The Cyanobacteria C. raciborskii, Planktothrix agardhii, Geitlerinema amphibium (C. Agardh) Anagnostidis and Pseudanabaena catenata Lauterborn, as well as the Chlorophyta Monoraphidium arcuatum (Korshikov) Hindák and Monoraphidium griffithii (Berkeley) Komárková-Legnerová, were common in both seasons. Anabaena constricta (Szafer) Geitler, Cyclotella meneghiniana Kützing, Synedra rumpens Kützing, Nitzschia sp. and Euglena sp. were abundant only in the rainy season. Abundant species accounted for $90.6 \%$ of the total density in the dry season, and $92.8 \%$ in the rainy season. C. raciborskii, P. agardhii and G. amphibium had the greatest densities and lowest coefficients of variation between depths throughout the study.

C. raciborskii was the only dominant species in the dry season, accounting for $69 \%$ of the total density. The greatest densities were also attributed to $C$. raciborskii in the rainy season, which accounted for $49.6 \%$ of the total phytoplankton community. However, this value did not constitute dominance.

\section{Principal Component ANALYSIS AND CANONICAL CORRESPONDENCE ANALYSIS}

Principal component analysis (PCA) explained 83.9\% in Factors 1 and 2, with a grouping of the species $A$. constricta (Aco), P. agardhii (Pag) and M. griffithii (Mgr) on the positive side of Axis 1 and a negative association (negative side of Axis 1), with a relationship between C. raciborskii (Cra) and water temperature 


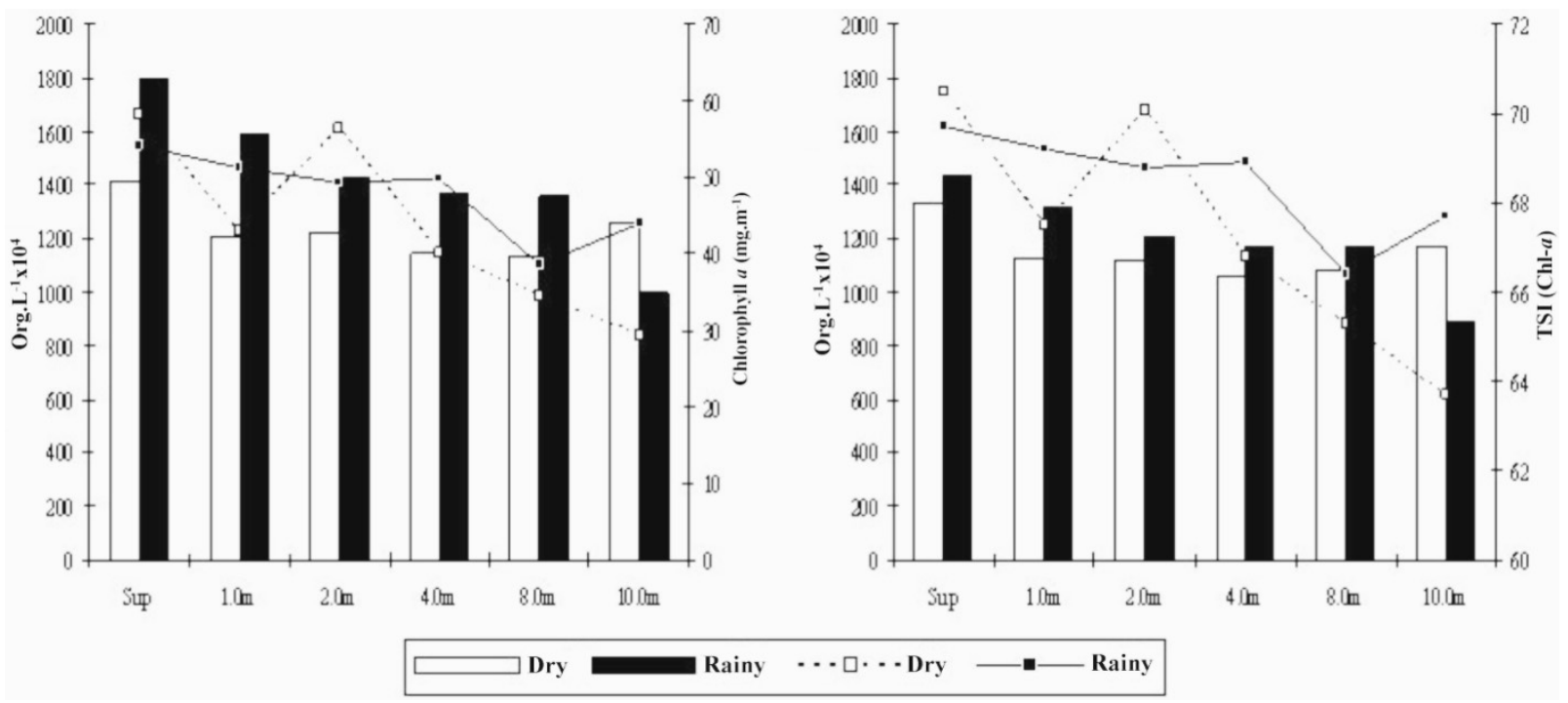

Fig. 2 -A) Variation in total phytoplankton density (columns) and Chlorophyll a (lines) between the analyzed depths. B) Variation in Cyanobacteria density (columns) and TSI (Chl-a) (lines) between depths analyzed in the Carpina reservoir (PE, Brazil) from January to November 2006.

$\left(\mathrm{T}^{\circ} \mathrm{C}\right)$. Also on the negative side of Axis 1, there was an association between conductivity (Cond) and total dissolved solids (TDS). On Axis 2, there was a positive association between dissolved oxygen (Oxy) and chlorophyll $a$ (Chl- $a$ ) (Fig. 4 and Table II).

The Monte Carlo test revealed that the correlation of the data from the canonical correspondence analysis was only significant $(\mathrm{p}<0.05)$ for Axis 1 , indicating a relationship between some of the environmental and biological variables (Table III). From an analysis of the canonical coefficients, total dissolved solids proved to be the variable of greatest importance in the scaling of the data. However, the "inter-set" correlations also revealed a strong influence of water temperature, electrical conductivity and $\mathrm{pH}$ over the species C. raciborskii and G. amphibium (Table IV and Fig. 5).

\section{DISCUSSION}

The monitoring of water quality using a biological approach is a relatively recent practice. These studies involving phytoplankton organisms in reservoirs represent a significant advance in the determination of water quality in these aquatic systems. The knowledge on the phytoplankton dynamics is relevant because temporal and spatial fluctuations in its composition and biomass may be efficient indicators of natural or antropic alterations in the aquatic ecosystems (Lira et al. 2009).
The phytoplankton community exhibited some variation in composition and richness between the dry and rainy seasons. However, these changes involved species classified as occasional in the ecosystem, accounting for less than $0.5 \%$ of the organisms quantified in each season. Changes were observed in species diversity and evenness, but such changes were not sufficient to alter the indicators of low diversity and nonhomogeneous distribution of individuals among the species. In eutrophic reservoirs, it is common to report low values for these indices, as environmental conditions in a situation of trophy tend to favor a small number of species that have large densities and alternate in the dominance of the community (Huszar et al. 1998, Figueiredo and Giani 2001, Chellapa and Costa 2003).

All the taxonomic groups in the Carpina reservoir had higher numbers of organisms in the rainy season, with greater contributions from Cyanobacteria and Chlorophyta. These changes were more evident in the first sampling in the period - a time of transition between seasons. According to others studies, this transition period causes greater instability in the phytoplankton community once the environmental characteristics of the new climatic season are not yet well defined, and the phytoplankton response occurs under the influence of the previous season (Figueiredo and Giani 2001, Dos Santos and Calijuri 1998). Thus, the higher water tem- 


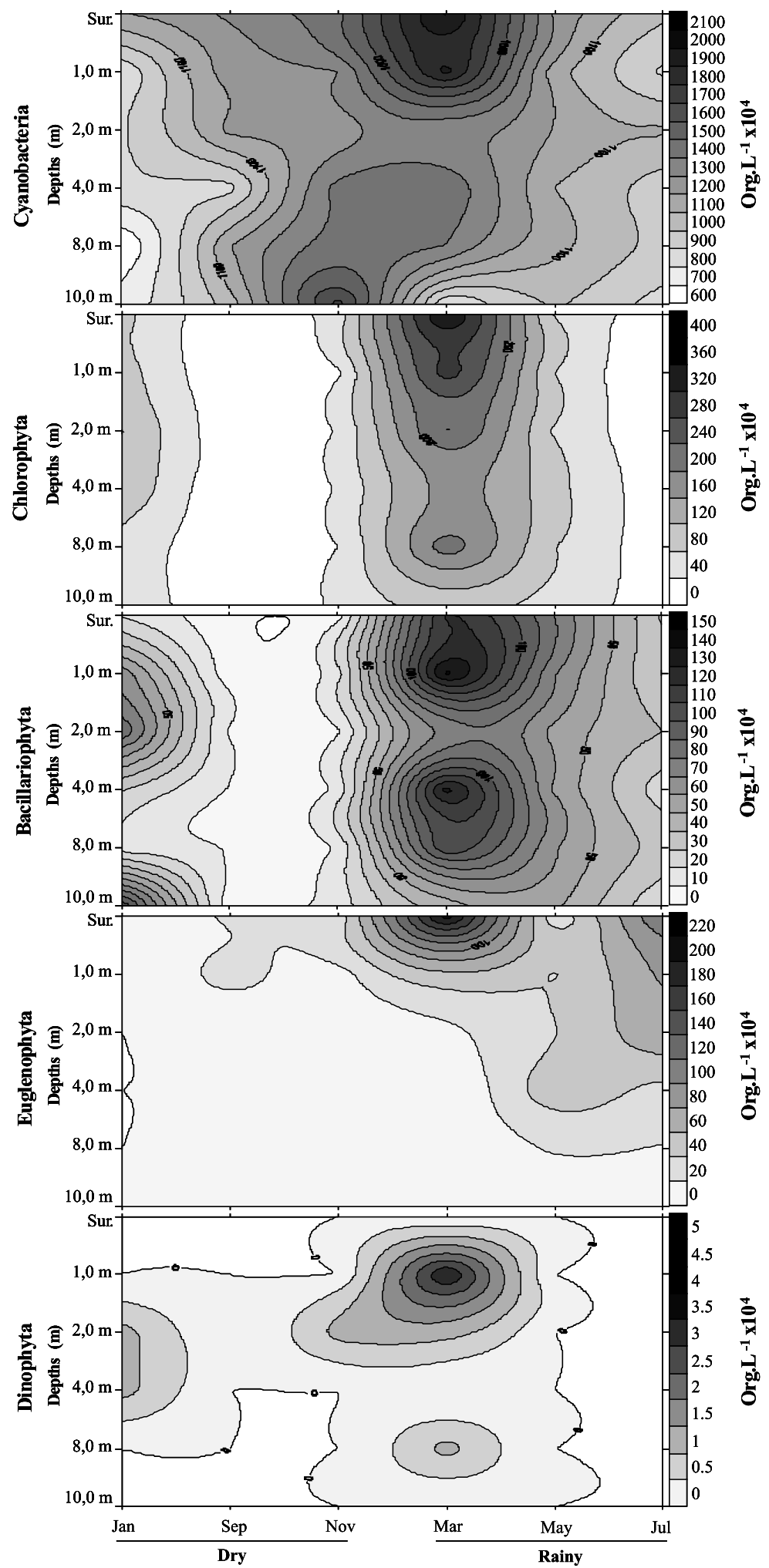

Fig. 3 - Density of phytoplankton groups $\left(\times 10^{4}\right.$ org.L $\left.L^{-1}\right)$ between depths analyzed in the Carpina reservoir (PE, Brazil) from January to November 2006. 


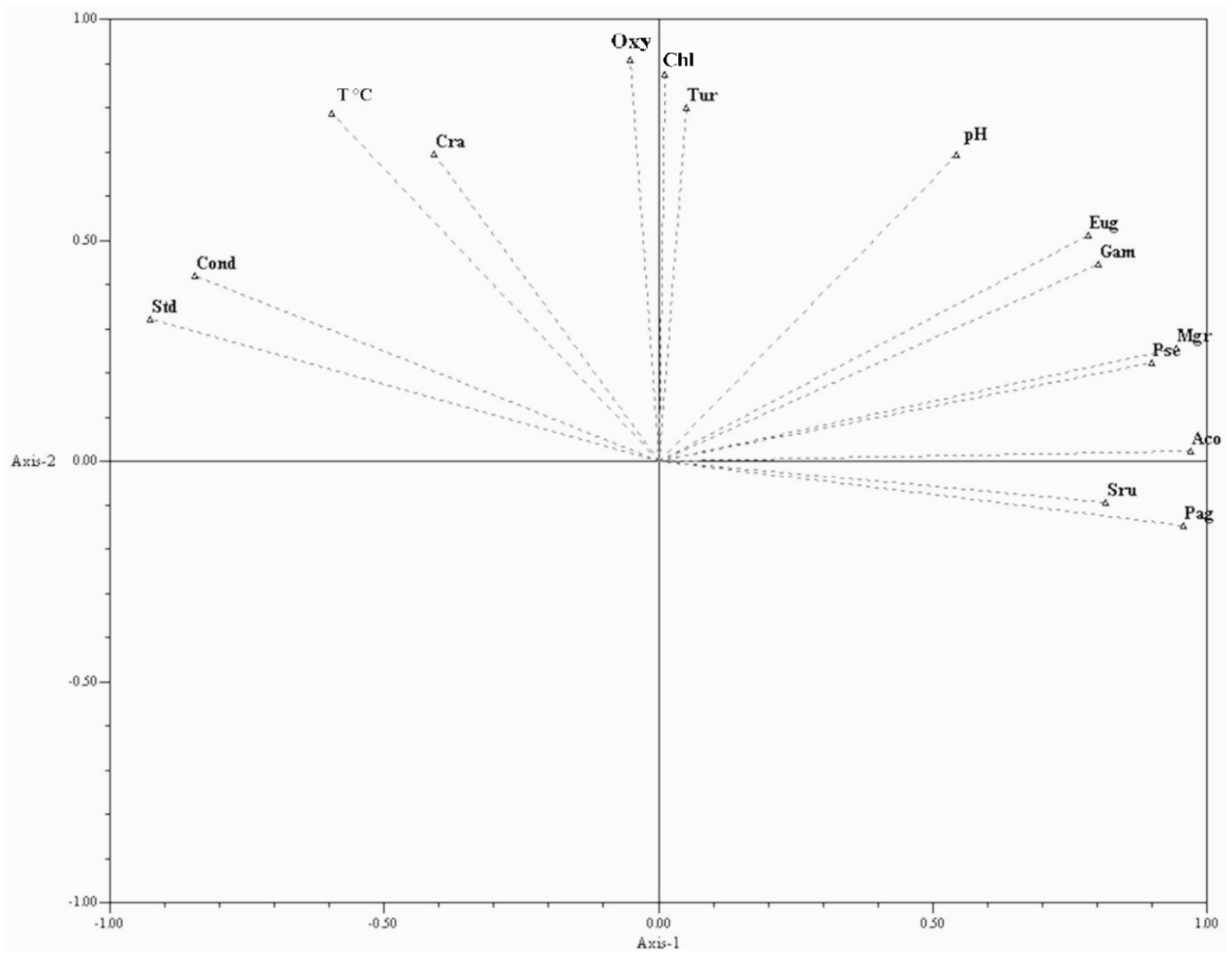

Fig. 4 - PCA of the most representative environmental and biological variables in the Carpina reservoir (PE, Brazil) from January to November 2006. Abbreviations: Aco (Anabaena constricta), Cra (Cylindrospermopsis raciborskii), Gam (Geitlerinema amphibium), Pag (Planktothrix agardhii), Pse (Pseudanabaena sp.), Sru (Synedra rumpens), Mgr (Monoraphidium griffithii), Eug (Euglena sp.), Chl- $a$ (Chlorophyll $a$ ), T ${ }^{\circ} \mathrm{C}$ (water temperature), Oxy (dissolved oxygen), Cond (electrical conductivity), TDS (total dissolved solids), Tur (turbidity) and pH.

perature was the variable with the greatest influence during the transition period in the Carpina reservoir.

Although there were higher values for a large part of the environmental parameters in the rainy season, the differences in comparison to the dry season were not particularly expressive. However, the statistical analyses reveal that the changes were sufficient to associate total dissolved solids, water temperature, electrical conductivity and $\mathrm{pH}$ to the growth of the phytoplankton community with the onset of the rains. The occurrence of seasonal models for many physiochemical parameters is common in tropical reservoirs, which are basically defined by the strong influence of rainfall (Huszar et al. 2000, Figueiredo and Giani 2001, Domitrovic 2003, Borges et al. 2008).

Although the rainy season led to a greater increase in the phytoplankton community of the Carpina reservoir, it also resulted in an expressive reduction in the density of C. raciborskii, which was previously dominant in the system. According to Bouvy et al. (2003) and Reynolds (1997), C. raciborskii has a low degree of affinity to increases in rainfall, which favors the coexistence of other species. Tucci and Sant'Anna (2003) agree with this opinion and attribute the morphology of C. raciborskii - which has fine, elongated trichomes - to the favoring of coexistent species during rainy periods, 
TABLE II

Correlation factors (\%) of principal component analysis (PCA) between abundance species and environmental variables in the Carpina reservoir

(PE, Brazil) from January to November 2006.

\begin{tabular}{c|l|c|c}
\hline Abbreviations & $\begin{array}{c}\text { Abundance species and } \\
\text { environmental variables }\end{array}$ & Factor 1 & Factor 2 \\
\hline$\%$ & Anabaena constricta & 20,23 & 14,35 \\
Aço & Cylindrospermopsis raciborskii & $-0,484$ & 0,125 \\
Cra & Geitlerinema amphibium & 0,552 & 0,669 \\
Gam & Planktothrix agardhii & 0,968 & $-0,519$ \\
Pag & Pseudanabaena catenata & 0,865 & 0,317 \\
Pse & Synedra rumpens & 0,828 & $-0,296$ \\
Sru & Monoraphidium griffithii & 0,908 & 0,355 \\
Mgr & Euglena sp. & 0,719 & 0,599 \\
Eug & Chlorophyll a & $-0,860$ & 0,886 \\
Chl & Water temperature & $-0,668$ & 0,719 \\
T C & Dissolved oxygen & $-0,131$ & 0,884 \\
Oxy & Electric conductivity & $-0,874$ & 0,316 \\
Cond & Total dissolved solids & $-0,954$ & 0,227 \\
Std & Turbidity & $-0,216$ & 0,782 \\
Tur & pH & 0,494 & 0,745 \\
Ph & &
\end{tabular}

TABLE III

Summary of CCA results for the most representative environmental and biological variables in the Carpina reservoir (PE, Brazil) from January to November 2006.

\begin{tabular}{l|c|c}
\hline & Axis 1 & Axis 2 \\
\hline Eigenvalue & 0.054 & 0.005 \\
\% of variance explained & 79.9 & 7.3 \\
Cumulative \% explained & 79.9 & 87.2 \\
Pearson Correlation (species - environment) & 0.998 & 0.938 \\
Monte Carlo Test (p) & & \\
$\quad$ Eigenvalue & 0.010 & 0.070 \\
$\quad$ Correlation species - environment & 0.010 & 0.080 \\
\hline
\end{tabular}

and for such it does not provide enough shade to impede an increase in the population of other species. However, it should be stressed that the majority of species that coexist in blooms of Cyanobacteria also form part of this group and are capable of living in adverse conditions and grow competitively when conditions are favorable (Hašler and Paulíčková 2003, Komárková and Tavera 2003, Bouvy et al. 2006). Although Cyanobacteria was dominant throughout the study and there was an increase in density with the onset of the rains, its repres- entativity within the community decreased by approximately $9.5 \%$, which was due to the increase in the populations of opportunistic species from other phytoplankton groups (S. rumpens and Euglena sp.), as well as the reduction in the $C$. raciborskii population.

In the eutrophic Gargalheiras reservoir in the state of Rio Grande do Norte (northeastern Brazil), some species of Cyanobacteria that establish dominance in the dry season (including $C$. raciborskii) have been found to undergo a significant numerical reduction in the rainy 
TABLE IV

Canonical coefficients and "inter-set" correlation coefficients for the most representative environmental and biological variables on Axes 1 and 2 of the CCA in the Carpina reservoir (PE, Brazil) from January to November 2006.

\begin{tabular}{l|c|c|c|c}
\hline & \multicolumn{2}{|c|}{ Canonical coefficients } & \multicolumn{2}{c}{ Inter-set correlations } \\
\cline { 2 - 5 } & Axis 1 & Axis 2 & Axis 1 & Axis 2 \\
\hline Water temperature $\left(\mathrm{T}^{\circ} \mathrm{C}\right)$ & -0.114 & -0.845 & 0.669 & -0.585 \\
Dissolved oxygen $(\mathrm{Oxy})$ & 0.403 & -1.834 & 0.038 & -0.815 \\
Electric conductivity (Cond) & 0.136 & 0.336 & 0.909 & -0.069 \\
Total dissolved solids (Std) & 0.718 & 0.953 & 0.983 & -0.082 \\
Turbidity (Tur) & -0.127 & 0.502 & 0.030 & -0.459 \\
$\mathrm{Ph}$ & -0.446 & 1.182 & -0.526 & -0.609 \\
\hline
\end{tabular}

season and take on the status of coexistence (Chellapa and Costa 2003). Conditions of greater stability of the water column, increased precipitation and dilution of nutrients have been indicated as the environmental factors that favor the reduction of Cyanobacteria species and the establishment of opportunistic taxa (Bouvy et al. 2003, Tucci and Sant'Anna 2003). The study of seasonal dynamics and toxicity of C. raciborskii in Lake Guiers (Senegal, West Africa) revealed that the ecological success attributed to this species is due to its large-scale tolerance to different climatic conditions (Berger et al. 2006).

In the present study, the stability of the water column, increased transparency and high water temperature in the rainy season provided conditions of competitive equality among the opportunistic species, leading to a reduction in the dominance of $C$. raciborskii.

A number of species found in the Carpina reservoir, such as $P$. agardhii, A. constricta and $P$. catenata, were also sensitive to the increased rainfall, but are opportunists and establish rapid growth in situations of increased light penetration. Species from the genus Monoraphidium and diatomaceae are generally characterized as opportunistic in conditions of luminosity and are tolerant to turbulent environments (Dos Santos and Calijuri 1998). In the present study, M. griffithii and $S$. rumpens exhibited an exceptional growth in the rainy season, when the conditions of light penetration and stability of the water column were better than in the dry season and therefore favorable to an increase in competitiveness.

Some studies report that the vertical distribution of phytoplankton species depends on a set of factors that involve the morphology and physiology of the taxa, as well as interactions between water mixture patterns and the availability of light and nutrients (Huszar et al. 2000, Bouvy et al. 2006, Borges et al. 2008). The concentration of the phytoplankton groups throughout the water column in the Carpina reservoir had different distribution patterns in the different seasons. In the dry season, the distribution of Cyanobacteria and Chlorophyta was homogenous, whereas the distribution of Bacillariophyta, Euglenophyta and Dinophyta was heterogeneous, with densities concentrated at few depths. In the rainy season, all groups exhibited a similar behavior, with greater concentrations at the surface and at a depth of $1.0 \mathrm{~m}$.

The Carpina reservoir did not exhibit expressive differences regarding phytoplankton composition (species richness). There were seasonal and vertical changes involving occasional species with low representativity in the community. The reservoir had a high degree of trophy and high densities of phytoplankton throughout the entire study, which was made up mostly by Cyanobacteria benefiting from the environmental conditions and their innate competitive advantages. Rainfall governed the differences in phytoplankton density found between species and affected the dominance of Cyanobacteria, especially the species C. raciborskii. Although relatively low, the reduction in the dominance of this group in the rainy season was sufficient for the establishment of opportunistic species, which achieved the status of coexistence. Although discreet, the changes in the environmental parameters between seasons and throughout the water column were important to reveal the instabil- 


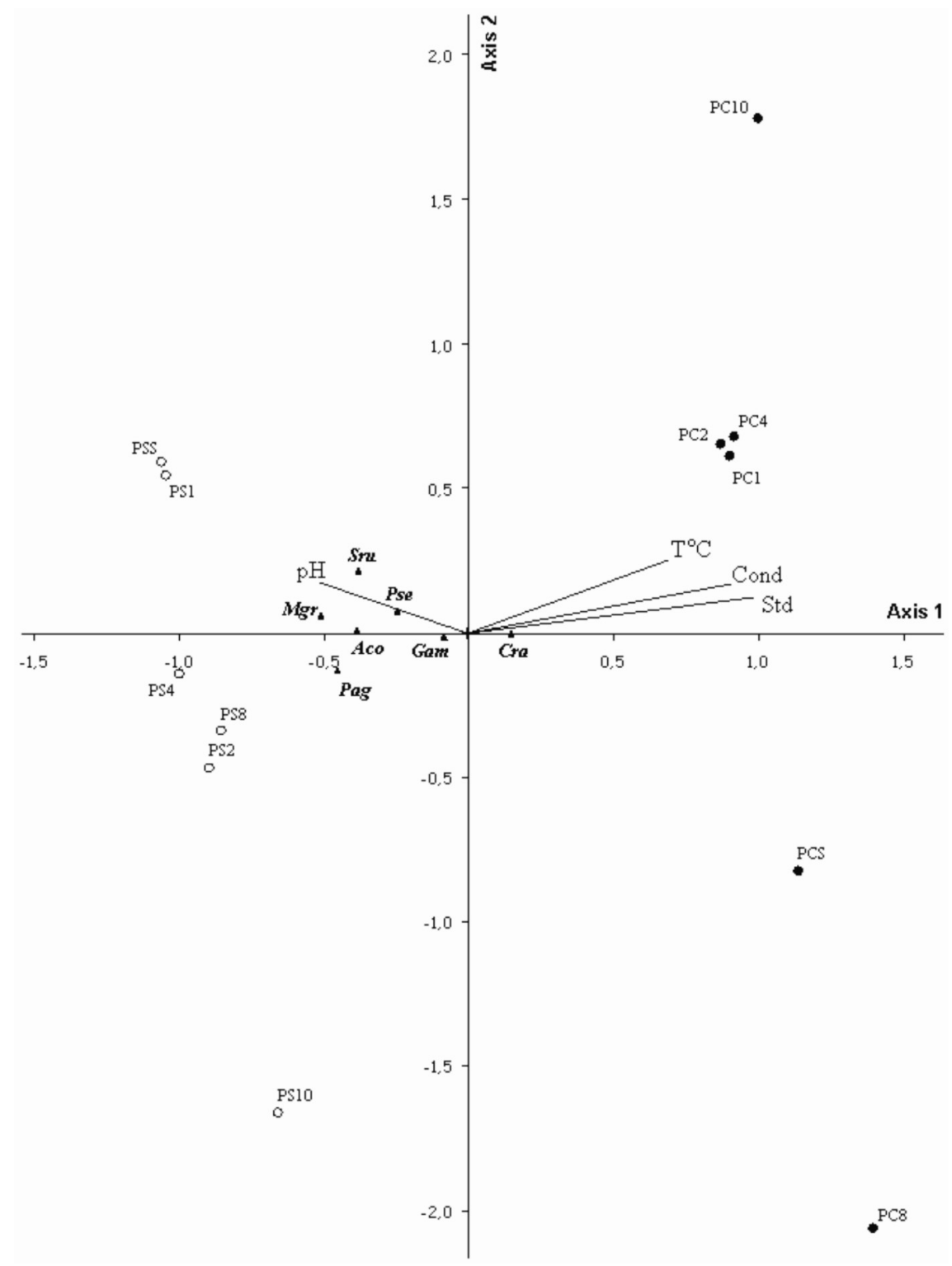

Fig. 5 - CCA scaling of the most representative environmental and biological variables in the Carpina reservoir (PE, Brazil) from January to November 2006. Abbreviations: Aco (Anabaena constricta); Cra (Cylindrospermopsis raciborskii); Pag (Planktothrix agardhii); Gam (Geitlerinema amphibium); Pse (Pseudanabaena sp.); Sru (Synedra rumpens); $\mathrm{Mgr}$ (Monoraphidium griffithii); $\mathrm{T}^{\circ} \mathrm{C}$ (water temperature), Oxy (dissolved oxygen), Cond (electrical conductivity), TDS (total dissolved solids), Tur (turbidity) and pH; DS (dry season); RS (rainy season); depths (S surface; 1-1.0 m; 2-2.0 m; 4-4.0 m; 8-8.0 m; 10-10.0 m).

ity of the system and demonstrate that precipitation and water temperature are the main regulating factors of the phytoplankton community in tropical ecosystems.

\section{ACKNOWLEDGMENTS}

The Conselho Nacional de Desenvolvimento Científico e Tecnológico $(\mathrm{CNPq})$ by scholarship awarded by the first author, Pos Graduate Program in Botany and Federal Rural University of Pernambuco by the use of facilities for the development of the study.

\section{RESUMO}

O presente estudo remete às relações de abundância, dominância e co-existência fitoplanctônica no reservatório eutró- 
fico de Carpina, Pernambuco, Brasil. Foram realizadas amostragens bimensalmente, em seis profundidades, em um único ponto do reservatório, contemplando dois períodos sazonais: seco (janeiro, setembro e novembro/2006) e chuvoso (março, maio e julho/2006). A densidade, abundância, dominância, diversidade específica e equitabilidade foram determinadas, além da clorofila a e algumas variáveis físicas e químicas do ambiente. Oito táxons foram considerados abundantes e suas densidades corresponderam a mais de $90 \%$ do fitoplâncton total quantificado. As cianobactérias representaram mais de $80 \%$ desta densidade. Cylindrospermopsis raciborskii foi o único táxon dominante durante o período seco e co-dominante no chuvoso. C. raciborskii, Planktothrix agardhii e Geitlerinema amphibium destacaram-se com as maiores densidades e os menores coeficientes de variação vertical. As análises estatísticas indicaram relação entre as alterações verticais e sazonais da comunidade fitoplanctônica e seguintes variáveis: sólidos totais dissolvidos, temperatura da água, condutividade elétrica e pH. As alterações observadas para as variáveis ambientais foram discretas e reguladas pelo estabelecimento das precipitações, no entanto foram capazes de promover instabilidade vertical e sazonal na estrutura da comunidade fitoplanctônica.

Palavras-chave: reservatório de Carpina, Cylindrospermopsis raciborskii, cianobactérias, características limnológicas, estrutura fitoplanctônica, distribuição vertical.

\section{REFERENCES}

Berger C, Ba N, Gugger M, Bouvvy M, Rusconi F, Coute A, Troussellier M And Bernard C. 2006. Seasonal dynamics and toxicity of Cylindrospermopsis raciborskii in Lake Guiers (Senegal, West Africa). Fed Eur Microbiol Soc (FEMS) 57: 355-366.

Borges PAF, TRAIN S AND Rodrigues LC. 2008. Spatial and temporal variation of phytoplankton in two subtropical Brazilian reservoirs. Hydrobiologia 607: 63-74.

Bouvy M, Ba N, Ka S, Sane S, Pagano M and Arfi R. 2006. Phytoplankton community structure and species assemblage succession in a shallow tropical lake (Lake Guiers, Senegal). Aquatic Microb Ecol 45: 147-161.

Bouvy M, Nascimento SM, Molica RJR, Ferreira A, Huszar V And Azevedo SMFO. 2003. Limnological features in Tapacurá reservoir (northeast Brazil) during a severe drought. Hydrobiologia 493: 115-130.

CARLSON RE. 1977. A trophic state index for lakes. University of Minnesota, Minneapolis. Contribution 141. Limnol Res Center 22: 361-369.
Chellappa NT AND Costa MAM. 2003. Dominant and co-existing species of Cyanobacteria from a eutrophicated reservoir of Rio Grande do Norte State, Brazil. Acta Oecol 24: 3-10.

Chorus I AND BARTRAM J. 1999. Toxic Cyanobacteria in water. A Guide to their Public Health Consequences, Monitoring and Management. London: E \& FN Spon WHO, $416 \mathrm{p}$.

Cole GA. 1975. Textbook of Limnology. Mosby: SaintLouis, $283 \mathrm{p}$.

Crossetti OL And Bicudo CEM. 2005. Structural and functional phytoplankton responses to nutrient impoverishment in mesocosms placed in a shallow eutrophic reservoir (Garças Pond), São Paulo, Brazil. Hydrobiologia 541: 71-85.

Domitrovic YZ. 2003. Effect of fluctuations in water level on phytoplankton development in three lakes of the Paraná river floodplain (Argentina). Hydrobiologia 510: 175193.

Dos SAntos ACA AND CALIJURI MC. 1998. Survival strategies of some species of the phytoplankton community in the Barra Bonita reservoir (São Paulo, Brazil). Hydrobiologia 367: 139-152.

Figueiredo CC AND Giani A. 2001. Seasonal variation in the diversity and species richness of phytoplankton in a tropical eutrophic reservoir. Hydrobiologia 445: 165174.

HAŠLER P AND POUlíČKOVÁ A. 2003. Diurnal changes vertical distribution and morphology of a natural population of Planktothrix agardhii (Gom.) Anagnostidis et Komárek (Cyanobacteria). Hydrobiolgia 506/509: 195-201.

Huszar VLM, Silva LHS, Domingos P, Marinho M AND MELo S. 1998. Phytoplankton species composition is more sensitive than OECD criteria to the trophic status of three Brazilian Tropical lakes. Hydrobiologia 369/370: 59-71.

Huszar Vlm, Silva LhS, Marinho M, Domingos P AND SANT'ANNA CL. 2000. Cyanoprokaryote assemblages in eight productive tropical Brazilian waters. Hydrobiologia 424: 67-77.

JOCHIMSEN EM ET AL. 1998. Liver failure and death after exposure to microcystins at a hemodialysis center in Brazil. Waltham. New Engl J Med 338: 873-878.

Kormaková J AND TAVERA R. 2003. Steady state of phytoplankton assemblage in the tropical Lake Catemaco (Mexico). Hydrobiologia 502: 187-196.

Lira GAST, BitTencourt-Oliveira MC And Moura AN. 2009. Structure and dynamics of phytoplankton community in the Botafogo reservoir - Pernambuco-Brazil. Brazil. Braz Arch Biol Technol 52: 493-501. 
LOBO E AND LEIGHTON G. 1986. Estructuras comunitarias de las fitocenosis planctonicas de los sistemas de desembocaduras de rios y esteros de la zona central de Chile. Rev Biol Mar 22: 1-29.

Margalef R. 1983. Limnologia. Barcelona: Ediciones Omega, $1010 \mathrm{p}$.

Molica R, Oliveira EJA, Carvalho PVVC, Costa ANSF, Cunha MCC, Melo GL and Azevedo AMFO. 2005. Occurrence of saxitoxins and an anatoxin$a(\mathrm{~s})$-like anticholinesterase in a Brazilian drinking water supply. Harmful Algae 4: 743-753.

Moura AN, Dantas EW and BitTencourt-Oliveira

MC. 2007. Structure of the phytoplankton in a water supply system in the state of pernambuco Brazil. Braz Arch Biol Technol 50: 645-654.

PIELOU EC. 1977. Mathematical Ecology. New York: WileyInterscience, $385 \mathrm{p}$.

Poole HH And AtKins WRG. 1929. Photoelectric measurements of submarine illumination through out the year. J Mar Biol Assoc 16: 297-324.

REYNOLDS CS. 1997. Vegetation processes in the pelagic: A model for ecosystem theory. Germany: Ecology Institute, $371 \mathrm{p}$.
ThORNTON KM, KiMMEL LB AND FONEST EP. 1990. reservoir limnology ecological perspectives. New York: J Wiley \& Sons, New York, USA, 246 p.

Toledo JR AP, TAlarico M, Chinez SJ AND AGUdo EG. 1983. Aplicação de modelos simplificados para a avaliação de processo de eutrofização em lagos e reservatórios tropicais. In: ANAIS DO CONGRESSO BRASILeiro de Engenharia SAnitária. Camboriu, p. 134.

TuCCI A AND SANT'AnNA CL. 2003. Cylindrospermopsis raciborskii (Woloszynska) Seenayya \& Subba Raju (Cyanobacteria): variação semanal e relações com fatores ambientais em um reservatório eutrófico, São Paulo - SP, Brasil. Rev Bras Bot 26: 97-112.

UTERMÖHL H. 1958. Zur Vervolkommung der quantitativen Phytoplankton - Mitt. Inter. Verein. Theor. Angew. Limnol 9: 1-38.

Villafaiñe VE ANd Reid FMH. 1995. Métodos de microscopia para la cuantificación del fitoplancton. In: ALVEAL K, Ferraro Me, Oliveira EC and Sar E (Eds), Manual de Métodos Ficológicos, Concepción, Universidad de Concepción, p. 169-185. 